\title{
On the Teaching Reform of Applied Mathematics in Colleges and Universities and the Cultivation of Students' Applied Mathematics Consciousness
}

\author{
Yihang Zhu, Shuhan Chen* \\ Zhejiang Normal University, Jinhua, China \\ Email: ${ }^{\star} 1272428472 @ q q . c o m$
}

How to cite this paper: Zhu, Y.H. and Chen, S.H. (2022) On the Teaching Reform of Applied Mathematics in Colleges and Universities and the Cultivation of Students' Applied Mathematics Consciousness. Open Access Library Journal, 9: e8330.

https://doi.org/10.4236/oalib.1108330

Received: December 27, 2021

Accepted: January 22, 2022

Published: January 25, 2022

Copyright $\odot 2022$ by author(s) and Open Access Library Inc.

This work is licensed under the Creative Commons Attribution International License (CC BY 4.0).

http://creativecommons.org/licenses/by/4.0/

\begin{abstract}
This paper mainly analyzes how to carry out the teaching of students' applied mathematics consciousness in the process of college applied mathematics teaching reform. The aim is to further improve the teaching quality and efficiency of applied mathematics and promote the optimization and reform of teaching mode in colleges and universities.
\end{abstract}

\section{Subject Areas}

Educational Reform, Mathematics Education

\section{Keywords}

Applied Mathematics in Universities, Teaching Reform, Students' Awareness of Applied Mathematics, To Cultivate

\section{Introduction}

In the process of teaching applied mathematics, we should pay more attention to training students to establish the learning consciousness of applied mathematics, so that they can make full use of applied mathematics knowledge, so as to become practical talents. In the teaching process of cultivating students' awareness of applied mathematics, teachers need to actively try all kinds of innovative teaching methods to truly let students establish awareness of applied mathematics. Figure 1 shows the framework diagram of this study.

\section{Students' Awareness of Mathematics Learning}

\subsection{Students' Mathematics Learning Objectives Are Vague}

Through daily observations can be found that the students in the process of 


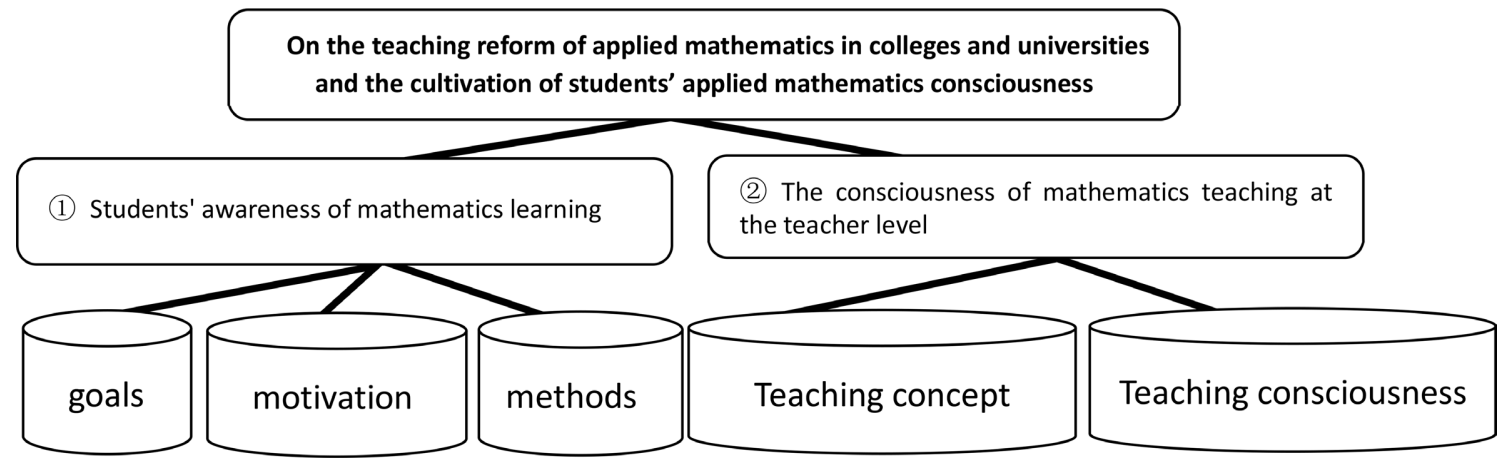

Figure 1. Framework diagram of this study.

mathematics classroom study, learning objectives more fuzzy problems are going to learn academic knowledge, lack of professional knowledge for the comprehensive cognition, the lack of rigorous planning of his life, academic, is blind and passive in the process of mathematics classroom learning. At the same time, many students have certain bias towards higher mathematics teaching, one-sided cognition, lack of understanding of their own majors, do not realize the current grim situation of employment, lack of a certain sense of urgency in employment, lack of autonomy and enthusiasm in the process of mathematics classroom learning.

On the knowledge structure of it, there are two large pieces of content, mathematics and application mathematics specialty one is related to the mathematics course, the other is related to computer course, the current computer field is one of the important application domains of mathematics knowledge, so the computer related courses setting is largely expand the professional employment channels. Computer courses mainly involve operating system, programming language and algorithm design, with emphasis on programming language learning. From the perspective of employment channels, the most common employment fields of this major include education, finance and IT industries, with positions involving teachers, data analysts and programmers. As these positions are in high demand, the employment prospects are relatively good. Due to the lack of planning in the learning activities of students in mathematics classroom, the learning objectives are chaotic, and the students lack the morale and willpower to work hard towards the learning objectives, so the quality of learning in mathematics classroom is relatively low.

\subsection{Students' Learning Motivation of Mathematics Is Not Strong}

By analyzing the current situation of college mathematics classroom education, it can be found that students' learning motivation is not strong, mainly due to the dual influence of internal factors and external factors. First of all, many students rely too much on their parents, which leads to the lack of independence and autonomy in campus life. They rely too much on their parents' help. They are used to asking others for help when facing problems, and they are not good at solving problems independently. From the psychological analysis, after the 
selection of the college entrance examination, students have different psychological changes after entering the university campus. After decades of hard study at a cold window, some students want to relax. Compared with some students, such students begin to deteriorate in psychological quality, externally, they often sit in the back of the classroom, do not listen to the teacher seriously or even play in class, and often cannot answer the teacher's simple questions and do homework perfunctorily [1]. Due to the lack of learning motivation, learning interest decreased, learning level gradually showed a decline. In terms of the teaching content, the concept of higher mathematics in university is more complex and abstract. For example, the concept of limit is emphasized to be accepted by students intuitively in middle school teaching, while in university students encounter such symbolic languages as E-N, E-6 and EX. Compared with middle school, a section of mathematics content in university is more informative. They take part in deeper and more complex theories on the new material, and after class they have to spend a lot of time digesting and understanding the material and secondly, many students enter colleges and universities because of their failure in the high school entrance examination. They have a poor cultural foundation and lack confidence in learning, and they are also prone to encounter difficulties in professional learning. Successive failures will destroy students' confidence in learning, and there are certain psychological resistance and weariness [2]. In addition, in the current college mathematics classroom activities, teachers lack encouragement and affirmation for students, and students lack confidence and learning motivation to participate in mathematics classroom activities, resulting in low efficiency of mathematics classroom learning.

\subsection{Mathematics Learning Method Is Not Scientific Enough}

Due to the poor cultural foundation of students, the learning differences among students are also relatively large. In the process of accepting advanced mathematics teaching, students need to learn not only some cultural course knowledge, but also professional course knowledge. Therefore, it is difficult to learn in mathematics classroom. At the same time, many students in mathematics classroom learning, students lack of learning methods training and guidance, can not obtain systematic, scientific learning methods, resulting in students' mathematics classroom learning efficiency is relatively low. Secondly, students' thinking is relatively fixed in mathematics classroom learning activities. No matter it is cultural knowledge inquiry or professional knowledge inquiry, students cannot draw inferences from one to the other.

\section{Mathematics Teaching Consciousness at the Teacher Level}

\subsection{Teachers Should Update Their Own Teaching Ideas and Establish Students' Awareness of Applied Mathematics in the Teaching Process}

For the reform of mathematics education and teaching in colleges and universi- 
ties, we should first start with teachers' teaching ideas, pay attention to the role of teaching idea innovation in promoting teaching reform in colleges and universities, and teachers should understand the long-term development trend of current teaching. Under the background of total social demand in the new era, it is imperative to cultivate a group of college students with innovative consciousness. Is, therefore, mathematics teachers should actively grasp the development trend of the current education, to their own teaching ideas to improve point [3], pay more attention to cultivate students to establish the consciousness of the applied mathematics, let the students knowledge of applied mathematics, can't stay firmly on the initial impression in the textbook inherent formula, Students should be able to learn in real life, truly combine the theoretical knowledge of applied mathematics with the solution of practical problems, truly improve the quality of applied mathematics and practical ability of applied mathematics, and finally make students have both practical ability and innovative ability in the field of mathematics [4].

\subsection{Teachers Should Improve Students' Awareness of Applied Mathematics through Mathematical Modeling Activities}

Mathematical modeling activities can enable students to combine the theoretical knowledge of applied mathematics with the solution of practical problems, and then in the process of in-depth exploration of mathematical knowledge, can realize the value and scientific nature of applied mathematical knowledge in specific fields. It also plays a very positive role in promoting the innovation ability of college students and the cultivation of professional quality. In the process of using mathematical modeling to organize teaching activities, students should first understand the relevant concepts and knowledge in the field of mathematical modeling, and then understand the specific concepts and laws of relevant mathematical knowledge to be used, and then carry out teaching activities about mathematical modeling on this basis. Further enhance the applied mathematics consciousness and thinking of college students [5].

\section{Conclusion and Recommendations}

\subsection{Conclusion}

Combined with the above research can find that in the process of the application of mathematics teaching in colleges and universities, from the perspective of teachers: the teacher wants to let the students set up the consciousness of the applied mathematics, you need to change their teaching ideas, such as through mathematical modeling and other activities to further improve students' understanding of applied mathematics, make students realize the importance of applied mathematics. From the perspective of students, advanced mathematics is the foundation and tool for engineering students to study professionally. Through learning advanced mathematics, students can strengthen the ability of creative thinking, highly abstract generalization and careful analysis of problems 
[1].

\subsection{Recommendations}

From the perspective of teachers: "taking effective ways to help students solve the problems and difficulties encountered in learning this course, improve students' interest and confidence in learning higher mathematics, encourage students to establish cooperative learning groups and establish contacts with students through various channels, and teachers and students actively explore and think together" is not only the need of the times, but also the need of higher mathematics teaching reform. From a student's perspective: For the students' mathematics learning interest, learning motivation remains to be enhanced, and the lack of scientific mathematics classroom learning methods and learning skills, aiming at the problem above, the university mathematics teachers need to change education idea, education mode [6], take students as the main object in mathematics classroom activities, guide students to discover problems, analyze and solve problems independently, to construct experiential, generative and interactive mathematics classroom education activities, let students deepen their understanding and memory of the knowledge of cultural courses and specialized courses, integrate theoretical knowledge with practical activities and improve students' professional quality, professional ability and comprehensive quality.

\section{Conflicts of Interest}

The authors declare no conflicts of interest.

\section{References}

[1] Xiong, S.Y. (2016) Cause Analysis and Optimization of Students with Learning Difficulties in Higher Mathematics. Examination Weekly, No. 20, 1.

[2] Zhang, X.M. (2008) On the Cultivation of Students' Reasonable Reasoning Ability in Junior Middle School Mathematics Teaching. Academic Review, No. 1, 3.

[3] Si, W. (2021) Analysis on the Teaching reform of Applied Mathematics in Colleges and Universities and the Cultivation of Students' Applied Mathematics Consciousness. Heilongjiang Science, No. 12, 122-123.

[4] Yuan, Y. (2015) On the Teaching Reform of Applied Mathematics in Universities and the Cultivation of Students' Applied Mathematics Consciousness. The Champ, No. 11,1 .

[5] Jiang, R.W. and Tang, J. (2021) Discussion on the Teaching Reform of Applied Mathematics in Colleges and Universities and the Cultivation of Students' Awareness of Applied Mathematics. Scientific Consulting (Science and Technology Management), No. 7, 289-290.

[6] Guo, Q. (2011) On the Cultivation of Students' Reasonable Reasoning Ability in Junior Middle School Mathematics Teaching. Exam Week, No. 43, 2. 